\section{ON A CASE OF \\ MYXCEDEMA, WITH REMARKS UPON THE ETIOLOGY OF THE DISEASE.}

By J. OSWALD LaNe, B.A., M.B. CaNtab., \&C. HOUSE-SURGEON TO THE NORTHAMPTON INFIRMARY.

M. R-, aged forty-eight, attended this hospital as one of Dr. Buszard's out-patients with the following history :Father and mother died of old age; one brother alive and healthy. There is no evidence of a neuropathic predisposition, neither does she know of any relatives who have been affected with a similar complaint. She has had six children, the last one eight years ago, from which time she dates her present illness. She denies having been laid up with any previous illness, though for some time after each confinement she was accustomed to feel very weak and unable to do ber work with her usual vigour. She had a particularly " bad time" at her last confinement, and has ever since suffered from weakness and debility. No syphilitic history; she remembers having been fiightened before her last confinement, and has had a good deal of mental anxiety. She complains of having had a feeling of lassitude, weakness, and nervousness since the above.mentioned date; at times has noticed giddiness, noises in the head, sparks in front of her eyes, with a feeling of pressure on vertex, disturbance of sleep, and loss of memory. Speech has become slower, with a pause between words. Walking slow and awkward; at times has fallen down. She has noticed the swelling of her face and hands only during the last six months, and she distinctly says that the nervous symptoms I have enumerated all preceded the latter. Has had sickness at times; has not passed much water.

When she first presented herself here her condition was as follows :- - Her physiognomy on the first glance was that of a person suffering from renal dropsy ; but on closer examinarion I found the cedema to be of a different character, in that it did not pit on pressure. The parts of the face most affected were the eyelids, lips, cheeks, and nose (the first two especially). The eyelids were pearly, semi-transparent, ridged, with drooping of the lower ones. The cheeks were puffy, so that the features were rounded in contour, with a circumscribed blush on both. The lips were pendulous, thick, and of a purplish tint. The nose was swollen, with dilated nostrils. The expression was stolid and sad, with a lack of mobility. The skin over the whole body was very dry and harsh ; the patient said it had been "scaly at times." The hands were markedly swollen, so as to be of a "spade-like" appearance, and were clumsy, with a dilatation of the capillaries on the dorsal surface. The lower extremities were not swollen. The patient had lost much of her hair, while many of the teeth were decayed. She had a train of nervous symptoms, such as slowness of speech, which was deliberate, monotonous, of nasal tone, frequently swallowing before speaking. The patient's movements were slow, and her gait awkward, with a feeling of being about to fall. She complained of headache and giddiness, and her memory was decidedly faulty. There was diminution of tactile sensation, and the conduction of sensory impulses was markedly retarded. The muscles acted very feebly to faradisation, and the reflexes were diminished, the patellar almost absent. Slre frequently feels chilly. There was no change in the thyroid glands. The heart sounds were normal, and not accentuated; no physical signs of hypertrophy. The lungs were normal. The urine was examined every time she attended, and I was unable to detect even the slightest trace of albumen, though numerous tests were used. The temperature varied between $96^{\circ}$ and $98^{\circ}$. The pulse was usually about 54, always slow. The ophthalmoscopic appearances were natural. The only drugs administered were iron, quinine, and strychnia.

I have published this case, first, as the patient seems to present most typically the symp om of myxodema; secondly, on account of the improvement the patient underwent during the four months she was under my observation, since at the end of that time her speech, gait, intelligence, and other nervous symptoms were decidedly improved, while the characteristic swelling had not made further progress; and, thirdly, the case is interesting on account of the absence of even a trace of albuminuria, or the presence of sny other sign of nephritic disease.
I would now make a few remarks as to what seems to me to be the probable etiology of the disease. In several cases which I have seen there seems to me to be a striking resemblance in the symptoms of the disease to some of those frequently developed in some forms of lesion of the central nervous system, and my reasons for thinking so are that the characteristic nervous symptoms of the disease are particularly constant, and that they have become distinctly well marked before any signs of oedema has developed itself ; in all the cases I have seen many nervous symptoms have been present, such as peculiar gait, slowness of speech, impaired sensation, subnormal reflexes, giddiness, impaired memory furthermore, in three cases the disease has shown itself after some mental shock or anxiety ; to this cause I would attribute the frequency of the disease in multiparæ, as a rapid succession of pregnancies combined with mental anxiety would probably lead to exhaustion of the system, and especially the nervous one ; in addition, many of the symptoms which present themselves are much allied to some of those observed in disseminated sclerosis and locomotor ataxv. The slowness of pulse and lowness of temperature are additional factors in aid of this hypothesis.

Northampton.

\section{d ettritrot}

\section{HOSPITAL PRACTICE, BRITISH AND FOREIGN.}

No.la autem est alia pro certo noscendi via, nisi quamplurimas et morborum et dissectionum historias, tum aliorum tum proprias collectas habere, et inter se comparare.-MongaGNi De Sed. et Caus. Morb., lib. iv. Proœmium.

\section{KING'S COLLEGE HOSPITAL}

PARALYSIS OF THE PALATE AND PHARYNX, COMPLICATED WITH PNEUMONIA, BOTH PROBABLY DIPHTHERITIC; RAPID RECOVERY; REMARKS.

(Under the care of Dr. FrRRIER.)

Fon the following notes we are indebted to Mr. St. Clair Thomson, M.R.C.S., house-physician.

David C - , aged thirty-four, a strong, healthy-looking Covent-garden porter, came to the out-patient department on April 12th, 1883, complaining of difficulty in swallowing. $\mathrm{He}$ then had complete paralysis of the palate. It did not rise either in inspiration or phonation, and gave no reflex action. There was no affection of the tongue or lips. $\mathrm{He}$ could pronounce all the vowels, but could not pronounce the explosives; the voice was nasal in tone. He could whistle if the nostrils were closed, but not otherwise. Liquids, on swallowing, came back through the nose, but if that was held he swallowed fairly well. On being questioned, he stated that he had had a sore-throat fourteen days previously, and that soon afterwards he noticed some difficulty in swallowing, owing to the tendency of fluids to return through the nose. No further history of diphtheria could be obtained. Late on the following evening, April 13th, he was admitted to the hospital, complaining of cough, feverish ness, and inability to swallow. His temperature was $1016^{\circ}$. The following morning he was found not to have slept at all, owing to the cough. He had swallowed nothing through the night. He was able to take milk into his mouth, bu was quite unable to swallow it, even with the nostrils closed the attempts to do so produced violent coughing and hawking. The voice was so nasal in tone that it was almost unintelligible; the condition of the palate remained as on the previons day. The temperature was $103^{\circ}$; the respiration 64, shallow, and chiefly thoracic; the cough was frequent, of a high-pitched, ringing character; the sputum, which was expelled with difficulty, was yellow and purulent. The front of the chest was resonant with scattered rhonchi and mucous râles; there was the same condition over the back of the right lung, and over the lef base there was complete dulness below the fourth rib, with fine inspiratory râles and marked bronchial breathing. The pulse was 136, fair quality, and regular; the cardiac area and sounds normal. The urine was acid, sp. gr. 1028, turbid with urates, but free from albumen. He was fed 